\title{
DEVELOPING AND VALIDATING AN HPLC METHOD TO QUANTIFY SIMULTANEOUSLY DUTASTERIDE AND THEIR RELATED MOLECULES (DUTASTERIDE ACID, 2,5 BIS- (TRI FLUORO METHYL)-ANILINE AND DUTASTERIDE 17 a-EPIMER) IN CAPSULES
}

\author{
Pola Srinivas $^{1^{*}}$ and Kancharlapalli Venkataramana ${ }^{2}$ \\ 'Department of Pharmacy, Acharya Nagarjuna University, \\ Andhra Pradesh, India. \\ ${ }^{2}$ Principal, ASN College of Pharmacy, Tenali, \\ Andhra Pradesh, India.
}

\begin{abstract}
Stability indicating HPLC method was suggested to simultaneously estimate dutasteride and their related molecules (dutasteride acid, 2,5 bis-(tri fluoro methyl)-aniline and dutasteride $17 \alpha$ epimer) in capsules. Stationary phase used was Inertsil ODS-3, $250 \mathrm{~mm} \times 4.6 \mathrm{~mm}$ column with $3 \mu$ particle dimension for separation, monitor and quantification. Mobile phase A (MP a) is a mixture of $0.42 \%$ perchloric acid buffer, acetonitrile and methanol in proportion 40:10: $50(\mathrm{v} / \mathrm{v} / \mathrm{v})$. Mobile phase $\mathrm{B}(\mathrm{MP} \mathrm{b})$ is a mixture of acetonitrile and water in proportion 90:10 (v/v). Elution was gradient mode with flow rate of $1.0 \mathrm{~mL} / \mathrm{min}$. The validation was carried out as stated by USP and ICH guiding principle. Linearity was obtained with concentration range of $0.466 \mu \mathrm{g} / \mathrm{mL}$ (LOQ level) - $7.6414 \mu \mathrm{g} / \mathrm{mL}$ for dutasteride acid, $0.3493 \mu \mathrm{g} / \mathrm{mL}$ (LOQ level) - $7.5599 \mu \mathrm{g} / \mathrm{mL}$ for 2,5 bis-(tri fluoro methyl)-aniline, $0.3962 \mu \mathrm{g} / \mathrm{mL}$ (LOQ level) - $7.6551 \mu \mathrm{g} / \mathrm{mL}$ for dutasteride $17 \alpha$-epimer and $0.4012 \mu \mathrm{g} / \mathrm{mL}$ (LOQ level) - $7.5294 \mu \mathrm{g} / \mathrm{mL}$ for dutasteride. The precision, accuracy, system suitability ruggedness and robustness results are within the criteria of acceptance. Hence, the developed and validated methodology stands for usage in routine analysis and stability sample analysis.
\end{abstract}

Keywords: Dutasteride, 2,5 Bis-(tri fluoro methyl)-aniline, Dutasteride $17 \alpha$-epimer.

\section{INTRODUCTION}

Dutasteride is an antiandrogenic 4-azasteroid molecule and belongs to medication category of 5 alpha- reductase inhibitors ${ }^{1,2}$. Dutasteride is chemically termed as (1S,3aS,3bS,5aR,9aR,9bS,11aS)-N-[2,5bis(trifluoromethyl)phenyl]-9a,11a-dimethyl-7oxo-1,2,3,3a,3b,4,5,5a,6,9b,10,11dodecahydroindeno[5,4-f]quinoline-1carboxamide (Figure 1). 5 alpha reductase is an intracellular enzyme which actually involved in transforming testosterone to 5 alphadihydrotestosterone ${ }^{3,4}$. Declining concentrations of dihydrotestosterone may alleviate or inhibit enlargement in prostate gland ${ }^{5}$. Dutasteride is used in males with an overactive prostate gland and to manage benign prostatic hyperplasia and baldness ${ }^{6,7}$.

Few methods to quantitatively assess Dutasteride have already been published. Contractor et al. ${ }^{8}$, Ranjani et al. ${ }^{9}$ and Myung et al. ${ }^{10}$ have developed LC-MS methods to quantify dutasteride in plasma of humans and rats. Dipti et al. ${ }^{11}$ described densitometric TLC for determining dutasteride in presence of degradants of acid, oxidative, alkali, photolytic, 
wet heat and dry heat. Kamila et al. $^{12}$ and Amin et al. $^{13}$ reported spectrophotometry methods for dutasteride estimation in pharmaceutical forms. Patel et al. ${ }^{14}$ and Navaneeswari et al. ${ }^{15}$ reported HPLC methods to separate and assay dutasteride in formulations. Reddy et al. proposed UPLC method to estimate dutasteride and impurities in bulk ${ }^{16}$.

This investigation was aimed at developing and validating a stability indicating HPLC method to monitor and quantify dutasteride and its impurities (dutasteride acid, 2,5 bis-(tri fluoro methyl)-aniline and dutasteride $17 \alpha$ epimer) simultaneously. The structures of studied impurities are shown in Figure 1.

\section{MATERIALS AND METHODS \\ Apparatus}

The chromatographic system used to perform development and validation of this method was comprised of a Make: Agilent; Model: 1200 Series, quaternary pump (G1311A model), auto sampler (G1329A model), Diode array detector ( $\mathrm{G} 1315 \mathrm{C}$ model) thermostated column (G1316A). System was controlled by version 4.0 EZChrome Elite software. Stationary phase used was Inertsil ODS-3, $250 \mathrm{~mm} \times 4.6 \mathrm{~mm}$ column with $3 \mu$ particle dimension.

\section{Drug, impurities and formulation}

Dutasteride (99.3\% purity) reference drug and Dutas capsule formulation $(0.5 \mathrm{mg}$ dutasteride per capsule) was gained as gift samples from Dr. Reddy's Laboratories (Hyderabad, India). Impurities like dutasteride acid (99.4\% purity), 2,5 bis-(tri fluoro methyl)-aniline ( $99.8 \%$ purity) and dutasteride $17 \alpha$-epimer (97.3\% purity) were obtained from SynThink Research Chemicals (Pune, India).

\section{CHEMICALS}

Analytical grade reagents hydrogen peroxide, perchloric acid, sodium hydroxide, phosphoric acid, hydrochloric acid are bought from Merck chemicals (Mumbai, India).

\section{SOLVENTS}

High performance chromatography grade solvents like methanol and acetonitrile are from Merck chemicals, Ramkem (Mumbai, India), respectively.

\section{Mobile phase and diluent}

Mobile phase A (MP a) is a mixture of $0.42 \%$ perchloric acid buffer, acetonitrile and methanol in proportion 40:10: $50(\mathrm{v} / \mathrm{V} / \mathrm{V})$. Mobile phase $B(M P$ b) is a mixture of acetonitrile and water in proportion 90:10(v/v). MP $a$ and $b$ was degassed using sonication for about $5 \mathrm{~min}$ and filtering via $0.45 \mu$ Nylon membrane filter. Acetonitrile was used as diluent and also as blank sample.

\section{Chromatographic conditions}

$\begin{array}{llll}\text { Flow rate } & \text { in } & : & 1.0 \mathrm{~mL} / \mathrm{min} \\ \text { column } & & \\ \text { Wavelength } & \text { for } & : & 210 \\ \text { detection } & \text { at } & : & 50^{\circ} \mathrm{C} \\ \begin{array}{l}\text { Temperature } \\ \text { column }\end{array} & & : & 75 \mathrm{~min} \\ \begin{array}{l}\text { Run time } \\ \text { Sample size }\end{array} & \text { for } & : & 15 \mu \mathrm{L} \\ \text { analysis } & & \\ \text { Elution mode } & & \text { : } & \text { Gradient }\end{array}$

\section{Gradient Program was set as follows}

\begin{tabular}{|c|c|c|c|c|c|c|c|c|}
\hline $\begin{array}{c}\text { Time } \\
\text { (min) }\end{array}$ & $\mathbf{0}$ & $\mathbf{1 5}$ & $\mathbf{4 0}$ & $\mathbf{5 0}$ & $\mathbf{5 5}$ & $\mathbf{6 0}$ & $\mathbf{6 5}$ & $\mathbf{7 5}$ \\
\hline $\begin{array}{c}\text { MP a } \\
(\%)\end{array}$ & 95 & 85 & 65 & 35 & 0 & 0 & 95 & 95 \\
\hline $\begin{array}{c}\text { MP b } \\
(\%)\end{array}$ & 5 & 15 & 35 & 65 & 100 & 100 & 5 & 5 \\
\hline
\end{tabular}

\section{Standard stock solutions}

Stock solutions of dutasteride $(25 \mu \mathrm{g} / \mathrm{mL})$, dutasteride acid $(25 \mu \mathrm{g} / \mathrm{mL}), 2,5$ bis-(tri fluoro methyl)-aniline $(25 \mu \mathrm{g} / \mathrm{mL})$ and dutasteride 17a-epimer (25 $\mu \mathrm{g} / \mathrm{mL})$ were prepared separately with diluent.

\section{Solutions for linearity study}

The stock solutions were mixed and diluted in appropriate proportions to get linearity solutions with concentration range of 0.466 $\mu \mathrm{g} / \mathrm{mL}$ - $7.6414 \mu \mathrm{g} / \mathrm{mL}$ (dutasteride acid), $0.3493 \mu \mathrm{g} / \mathrm{mL}$ - $7.5599 \mu \mathrm{g} / \mathrm{mL}$ (2,5 bis-(tri fluoro methyl)-aniline), $0.3962 \mu \mathrm{g} / \mathrm{mL}-7.6551$ $\mu \mathrm{g} / \mathrm{mL}$ (dutasteride17a-epimer) and 0.4012 $\mu \mathrm{g} / \mathrm{mL}$ - $7.5294 \mu \mathrm{g} / \mathrm{mL}$ (dutasteride).

\section{Solutions for precision}

The stock solutions were mixed and diluted in appropriate proportions to get standard solution with concentration $2.5 \mu \mathrm{\mu g} / \mathrm{mL}$ (dutasteride acid), $2.5 \mu \mathrm{g} / \mathrm{mL}$ (2,5 bis-(tri fluoro methyl)-aniline), $2.5 \mu \mathrm{g} / \mathrm{mL}$ (dutasteride17 $\alpha$ epimer) and $2.5 \mu \mathrm{g} / \mathrm{mL}$ (dutasteride).

\section{Solutions for accuracy}

The stock solutions were mixed and diluted in appropriate proportions to prepare solutions for accuracy. Solutions to study accuracy were prepared with diluent at 4 concentration levels (LOD level; $50 \%$ level, $100 \%$ level and $150 \%$ level). Twenty capsules were emptied, and contents were transferred to dry beaker. Accurately weighed $3000 \mathrm{mg}$ of oily solution equal to dutasteride $5 \mathrm{mg}$ were transferred to a $10 \mathrm{~mL}$ volumetric flask with dropper. Added $4 \mathrm{~mL}$ of diluent and sonicated for 10 min at room temperature, added appropriate 
volume of each (for LOD level $-0.1 \mathrm{~mL}$; for $50 \%$ level $-0.5 \mathrm{~mL}$; for $100 \%$ level $-1.0 \mathrm{~mL}$; for $150 \%$ level - $1.5 \mathrm{~mL}$ ) impurity stock standard solutions, diluted the volume to mark with diluent and mix carefully. Filtered sample solution through $0.45 \mu$ Nylon membrane filter.

\section{Concentrations at different levels are as follows \\ LOD level}

$0.466 \mu \mathrm{g} / \mathrm{mL}$ (dutasteride acid), $0.3493 \mu \mathrm{g} / \mathrm{mL}$ (2,5 bis-(tri fluoro methyl)-aniline) and 0.3962 $\mu \mathrm{g} / \mathrm{mL}$ (dutasteride17a-Epimer).

\section{$50 \%$ level}

$2.4875 \mu \mathrm{g} / \mathrm{mL}$ (dutasteride acid), 2.5449 $\mu \mathrm{g} / \mathrm{mL}$ (2,5 bis-(tri fluoro methyl)-aniline), $2.5420 \mu \mathrm{g} / \mathrm{mL}$ (dutasteride17 $\alpha$-Epimer).

\section{$100 \%$ level}

$4.9750 \mu \mathrm{g} / \mathrm{mL}$ (dutasteride acid), 5.0898 $\mu \mathrm{g} / \mathrm{mL}(2,5$ bis-(tri fluoro methyl)-aniline) and $5.0839 \mu \mathrm{g} / \mathrm{mL}$ (dutasteride17 $\alpha$-Epimer).

\section{$150 \%$ level}

$7.4625 \mu \mathrm{g} / \mathrm{mL}$ (dutasteride acid), 7.6347 $\mu \mathrm{g} / \mathrm{mL}$ (2,5 bis-(tri fluoro methyl)-aniline) and $7.6259 \mu \mathrm{g} / \mathrm{mL}$ (dutasteride17a-Epimer).

\section{Solutions for degradation study}

The placebo, dutasteride standard $(2.5 \mu \mathrm{g} / \mathrm{mL})$ and test sample (dutasteride - $2.5 \mu \mathrm{g} / \mathrm{mL}+$ placebo) were subjected to different stress degradation conditions based on $\mathrm{ICH}$ guidelines [17].

\section{Acid stressed sample solutions}

The placebo (3005.32 mg), dutasteride standard $(5 \mathrm{mg}$ ) and test sample (dutasteride $-5.2 \mathrm{mg}$ + placebo - 3005.25 mg) were added to $5 \mathrm{~mL}$ of methanol. $45 \mathrm{~mL}$ of $2 \mathrm{~N} \mathrm{HCl}$ was added to all flasks. The flasks were refluxed at $90^{\circ} \mathrm{C}$ for $2 \mathrm{hr} .50 \mathrm{~mL}$ of $2 \mathrm{~N} \mathrm{NaOH}$ was added to all flasks to neutralize the samples. The sample mixture was centrifuged at $3500 \mathrm{rpm}$ for $10 \mathrm{~min}$. $5 \mathrm{~mL}$ of supernatant solution was diluted to $100 \mathrm{~mL}$ with diluent and filtered via $0.45 \mu \mathrm{m}$ Nylon membrane filter.

\section{Alkali stressed sample solutions}

The placebo (3000.05 mg), dutasteride standard $(5 \mathrm{mg}$ ) and test sample (dutasteride $-5.0 \mathrm{mg}$ + placebo $-3000 \mathrm{mg}$ ) were added to $5 \mathrm{~mL}$ of methanol. $45 \mathrm{~mL}$ of $1 \mathrm{~N} \mathrm{NaOH}$ was added to all flasks. The flasks were refluxed at $90^{\circ} \mathrm{C}$ for $5 \mathrm{~min} .50 \mathrm{~mL}$ of $1 \mathrm{~N} \mathrm{HCl}$ was added to all flasks to neutralize the samples. The sample mixture was centrifuged at $3500 \mathrm{rpm}$ for $10 \mathrm{~min} .5 \mathrm{~mL}$ of supernatant solution was diluted to $100 \mathrm{~mL}$ with diluent and filtered via $0.45 \mu \mathrm{m}$ Nylon membrane filter.

\section{Peroxide stressed sample solutions}

The placebo (3000.59 mg), Dutasteride standard $(5.05 \mathrm{mg})$ and test sample (Dutasteride - $5.05 \mathrm{mg}$ + placebo - 3000.78 $\mathrm{mg}$ ) were added to $2 \mathrm{~mL}$ of methanol. $48 \mathrm{~mL}$ of $0.01 \%$ peroxide was added to all flasks. The flasks were refluxed at $90^{\circ} \mathrm{C}$ for $2 \mathrm{hr} .48 \mathrm{~mL}$ of $0.01 \%$ sodium meta bisulphate was added to all flasks. The sample mixture was centrifuged at $3500 \mathrm{rpm}$ for $10 \mathrm{~min} .5 \mathrm{~mL}$ of supernatant solution was diluted to $100 \mathrm{~mL}$ with diluent and filtered via $0.45 \mu \mathrm{m}$ Nylon membrane filter.

\section{Thermal stressed sample solutions}

The placebo (3000.84 mg), dutasteride standard $(5.01 \mathrm{mg})$ and test sample (dutasteride - $5.01 \mathrm{mg}+$ placebo - 3005.0 $\mathrm{mg}$ ) were placed in watch glass and subjected to $105^{\circ} \mathrm{C}$ for $48 \mathrm{hr}$ in a oven. After degradation time period, the samples were mixed with 70 $\mathrm{mL}$ of diluent, sonicated for $10 \mathrm{~min}$ and made to $100 \mathrm{~mL}$ with diluent. The sample mixture was centrifuged at $3500 \mathrm{rpm}$ for $10 \mathrm{~min} .5 \mathrm{~mL}$ of supernatant solution was diluted to $100 \mathrm{~mL}$ with diluent and filtered via $0.45 \mu \mathrm{m}$ Nylon membrane filter.

\section{UV stressed sample solutions}

The placebo (3000.64 mg), dutasteride standard $(5.20 \mathrm{mg})$ and test sample (dutasteride - $5.10 \mathrm{mg}$ + placebo - 3005.84 $\mathrm{mg}$ ) were placed in watch glass and subjected to UV light for $72 \mathrm{hr}$ in a UV chamber. After degradation time period, the samples were mixed with $70 \mathrm{~mL}$ of diluent, sonicated for 10 min and made to $100 \mathrm{~mL}$ with diluent. The sample mixture was centrifuged at $3500 \mathrm{rpm}$ for $10 \mathrm{~min} .5 \mathrm{~mL}$ of supernatant solution was diluted to $100 \mathrm{~mL}$ with diluent and filtered via $0.45 \mu \mathrm{m}$ Nylon membrane filter.

\section{Humidity stressed sample solutions}

The placebo (3000.81 mg), dutasteride standard $(5.10 \mathrm{mg})$ and test sample (dutasteride - $5.14 \mathrm{mg}$ + placebo - 3005.91 $\mathrm{mg}$ ) were placed in watch glass and subjected to $27^{\circ} \mathrm{C}$ or $90 \%$ humidity for 10 days. After degradation time period, the samples were mixed with $70 \mathrm{~mL}$ of diluent, sonicated for 10 min and made to $100 \mathrm{~mL}$ with diluent. The sample mixture was centrifuged at $3500 \mathrm{rpm}$ for $10 \mathrm{~min} .5 \mathrm{~mL}$ of supernatant solution was diluted to $100 \mathrm{~mL}$ with diluent and filtered via $0.45 \mu \mathrm{m}$ Nylon membrane filter.

\section{RESULTS AND DISCUSSION \\ Optimization of chromatography conditions}

For the simultaneous detection and quantification of dutasteride acid, 2,5 bis-(tri 
fluoro methyl)-aniline, dutasteride 17a-epimer and dutasteride in bulk and capsule formulations with good system suitability values, the conditions like column type, mobile phase composition, solvents ratio in mobile phase, mode of elution, flow rate of mobile phase, column temperature, wavelength for analysis injection volume of sample for analysis and total run time for one analysis were optimized through several trail operations. Finally, good system suitability values (resolution, peak tailing, peak shape and area response) were obtained in conditions given below:

$>$ Inertsil ODS column - 3, $250 \mathrm{~mm} \times 4.6$ $\mathrm{mm}$ and $3 \mu$ size of particle

$>$ MP a: $0.42 \%$ perchloric acid buffer, methanol and acetonitrile in ratio 40:50:10 $(v / v / v)$

$>\mathrm{MP} \mathrm{b}$ : Acetonitrile and water in ratio of 90:10 ( $v / v)$.

Gradient elution mode. The gradient programme is as follows

\begin{tabular}{|c|c|c|c|c|c|c|c|c|}
\hline $\begin{array}{c}\text { Time } \\
\text { (min) }\end{array}$ & $\mathbf{0}$ & $\mathbf{1 5}$ & $\mathbf{4 0}$ & $\mathbf{5 0}$ & $\mathbf{5 5}$ & $\mathbf{6 0}$ & $\mathbf{6 5}$ & $\mathbf{7 5}$ \\
\hline $\begin{array}{c}\text { MP a } \\
(\%)\end{array}$ & 95 & 85 & 65 & 35 & 0 & 0 & 95 & 95 \\
\hline $\begin{array}{c}\text { MP b } \\
(\%)\end{array}$ & 5 & 15 & 35 & 65 & 100 & 100 & 5 & 5 \\
\hline
\end{tabular}

$>1.0 \mathrm{~mL} / \mathrm{min}$ flow rate

$>50^{\circ} \mathrm{C}$ temperature

$>210 \mathrm{~nm}$ as wavelength for analysis

$>15 \mu \mathrm{l}$ as sample injection for analysis

$>75$ min as run time

The chromatogram of sample using optimized conditions is shown in Figure 2. The retention times are dutasteride acid - 8.04 min, 2,5 bis(tri fluoro methyl)-aniline - $16.92 \mathrm{~min}$, dutasteride 17a-epimer - $36.75 \mathrm{~min}$ and dutasteride - $38.83 \mathrm{~min}$. Clear resolution was seen between dutasteride and its impurities like dutasteride acid, 2,5 bis-(tri fluoro methyl)aniline and dutasteride 17a-epimer with optimized conditions.

With optimized chromatographic conditions, the relative retention time and relative responsive response factor for dutasteride acid, 2,5 bis-(tri fluoro methyl)-aniline, dutasteride 17a-epimer and dutasteride were calculated as using formula given below:

Retention time of impurity peak

Relative Retention Time $=$

Retention time of main peak
Slope of Impurity peak

Relative Response Factor=

Slope of main peak

The relative retention time and relative responsive response factor for dutasteride acid, 2,5 bis-(tri fluoro methyl)-aniline, dutasteride 17a-epimer and dutasteride are given in Table 1: Relative retention time and relative responsive response factor values of Dutasteride and its impurities.

\section{Validation}

The method described was validated in compliance of $\mathrm{ICH}$ guidelines for parameters accuracy, linearity, specificity, precision, selectivity, limit of detection, limit of quantification and robustness ${ }^{18}$.

\section{System suitability}

Diluent (acetonitrile) and standard solution (dutasteride $-2.5 \mu \mathrm{g} / \mathrm{mL}+$ dutasteride $17 \alpha-$ epimer $2.5 \mu \mathrm{g} / \mathrm{mL}$ ) was infused ( $n=6$ times) into the system and chromatographs were recorded. Criteria parameters for system suitability were computed. The criteria for system suitability shall always to be met. The acquired values (Table 2) illustrated the system's suitability to analyze dutasteride acid, 2,5 bis-(tri fluoro methyl)-aniline, dutasteride 17a-epimer and dutasteride simultaneously. (Table 2: Results for system suitability)

\section{Specificity}

Specificity was confirmed through placebo \& diluent interference study and impurity interference study.

\section{Placebo and diluent interference study}

Placebo was prepared using mono- and diglycerides, medium chain triglycerides, butylated hydroxy toluene, gelatin, tween 80 and FDC Red 40. Placebo and dilent solutions were infused into the chromatography system. The chromatograms obtained were checked for interference peaks at retention times of dutasteride, dutasteride acid, 2,5 bis-(tri fluoro methyl)-aniline, dutasteride 17a-epimer. No placebo (Figure 3a) and diluent (Figure 3b) related peaks were noted at retention times of dutasteride, dutasteride acid, 2,5 bis-(tri fluoro methyl)-aniline, dutasteride 17a-epimer. Therefore, there was no placebo and diluent interference.

\section{Impurity Interference study}

To check interference from impurities, all individual impurities are injected at 
specification level (dutasteride acid - 2.5 $\mu \mathrm{g} / \mathrm{mL}, 2,5$ bis-(tri fluoro methyl)-aniline- 2.5 $\mu \mathrm{g} / \mathrm{mL}$, dutasteride $17 \alpha$-epimer $-2.5 \mu \mathrm{g} / \mathrm{mL}$ ). Impurities are added to test sample at specification level and Injected into HPLC system. Control samples were also injected. The impurities were separated from each other and from dutasteride peak. The peak purity of dutasteride peak in control sample and the peak purity of dutasteride, dutasteride acid, 2,5 bis-(tri fluoro methyl)-aniline, dutasteride $17 \alpha$-epimer in added samples was more than 0.990 . No additional peaks of blank and placebo were observed at retention times of dutasteride, dutasteride acid, 2,5 bis-(tri fluoro methyl)-aniline, dutasteride 17a-epimer. Peaks of dutasteride related substances are not interfered with dutasteride and also from each other. The chromatograms of this test were given in Figures $4 a-4 f$. Hence, the method was selective and specific.

\section{Linearity}

Linearity test was tested from the LOQ level concentration to $150 \%$ level concentration of dutasteride, dutasteride acid, 2,5 bis-(tri fluoro methyl)-aniline and dutasteride 17a-epimer. Linearity was seen in range of $0.466-7.6414$ $\mu \mathrm{g} / \mathrm{mL}$ (dutasteride acid), 0.3493 - 7.5599 $\mu \mathrm{g} / \mathrm{mL}$ (2,5 bis-(tri fluoro methyl)-aniline), 0.3962 - $7.6551 \mu \mathrm{g} / \mathrm{mL}$ (dutasteride 17aepimer) and 0.4012 - $7.5294 \mu \mathrm{g} / \mathrm{mL}$ (dutasteride). The regression statistic values for the linearity were given Table 3 . It is obvious in the above information that perhaps the response was linear. Coefficients of correlation are $>0.990$. Furthermore, the residual assessment revealed that the values were spread randomly around zero, which fits well within linearity model. The quantitative method is therefore linear. (Table 3: regression statistic values for dutasteride and its impurities).

\section{Limit of detection and quantification}

Detection (LOD) and quantification (LOQ) limit was determined by the slope and linearity curve

residual standard deviation as framed by $\mathrm{ICH}$ set of laws. The computed values are given in Table 4.

The quantitative method was adequate enough for the intended use (Table 4: Sensitivity results for dutasteride and impurities).

\section{Precision}

\section{Method precision}

Six times evaluated the samples (dutasteride acid - $2.5 \mu \mathrm{g} / \mathrm{mL}, 2,5$ bis-(tri fluoro methyl)aniline $-2.5 \mu \mathrm{g} / \mathrm{mL}$, dutasteride $17 \alpha$-epimer -
$2.5 \mu \mathrm{g} / \mathrm{mL}$ and dutasteride - $2.5 \mu \mathrm{g} / \mathrm{mL}$ ) according to the procedure established. The quantity of dutasteride and total impurities as well as their relative standard deviation. Relative standard deviation calculated were less than $10 \%$ (Table 5) and proved method precision (Table 5: Method precision findings for individual impurities and dutasteride).

\section{Intermediate precision}

Six times evaluated the samples (dutasteride acid $-2.5 \mu \mathrm{g} / \mathrm{mL}, 2,5$ bis-(tri fluoro methyl)aniline $-2.5 \mu \mathrm{g} / \mathrm{mL}$, dutasteride $17 \alpha$-epimer $2.5 \mu \mathrm{g} / \mathrm{mL}$ and dutasteride $-2.5 \mu \mathrm{g} / \mathrm{mL}$ ) as per the procedure established by distinct analyst using separate column lots on distinct devices and distinct days. The quantity of dutasteride and total impurities as well as their relative standard deviation. Relative standard deviation calculated were less than $10 \%$ (Table 6) and proved intermediate precision and ruggedness (Table 6: Intermediate precision/ruggedness findings for individual impurities and dutasteride).

\section{Accuracy}

Accuracy was tested by spiking the known amount of dutasteride, dutasteride acid, 2,5 bis-(tri fluoro methyl)-aniline and dutasteride $17 \alpha$-epimer in capsule sample with different (4) levels varying from LOQ to $150 \%$ specification level. Recovery was conducted at each level in triplicate. The recovery of dutasteride, dutasteride acid, 2,5 bis-(tri fluoro methyl)-aniline and dutasteride 17a-epimer was calculated. Percent recoveries determined were within $70 \%-130 \%$ (acceptance criteria) at LOQ level and within $85 \%$ - $115 \%$ (acceptance criteria) at other levels (Table 7). Percent relative standard deviation got for 12 determinations were not more than $15 \%$. The method is therefore accurate Table 7: Accuracy for impurities at varying concentration levels.

\section{Robustness}

The method's robustness was researched through intentional method modifications such as modifications in flow rate, temperature, organic solvent ratio, and wavelength. Values for RRT are measured in all modified conditions. It has been noted that there have been no noticeable changes in RRT values. The values acquired are given in Table 8 and showed that the procedure is robust Table 8: Robustness findings - RRT and their differences).

\section{Specificity (forced degradation)}

Forced degradation of dutasteride capsules is performed to ensure that any degradation 
product, if found, will not clash with dutasteride peak and with each other during the stability testing. The forced degradation research was done through exposing the sample to oxidative lysis, alkali lysis, acid lysis, photolytic, dry heat and humidity. The results of degradation are given in Table 9. The chromatograms are given in Figures $5 a-5 f$. The known and unknown degradants are separated from dutasteride peak and with each other. The peak purity of dutasteride peak in stressed sample was $<0.990$ and mass balance was $<95 \%$. The procedure is therefore considered specific and stability indicating (Table 9: Forced Degradation results of dutasteride capsules).

\section{CONCLUSION}

Stability indicating HPLC method was suggested to simultaneously estimate dutasteride and related molecules of dutasteride in capsules. The validation for the estimation of related molecules of dutasteride capsules is carried out as stated by USP and $\mathrm{ICH}$ guiding principle. The precise and robust protocol is found as specific for estimation of known impurities, unknown impurities and degradation products. The method proved stability indicating through degradation study. The procedure is found as linear and accurate in specified range determined. The limit of quantification values established was less than of the reporting threshold. Hence the suggested procedure stands for usage of routine and stability sample analysis.

Table 1: Relative retention time and relative responsive response factor values of Dutasteride and its impurities

\begin{tabular}{|c|c|c|}
\hline Impurity or drug & $\begin{array}{c}\text { Relative } \\
\text { retention } \\
\text { time }\end{array}$ & $\begin{array}{c}\text { Relative responsive } \\
\text { response factor }\end{array}$ \\
\hline Dutasteride Acid & 0.21 & 0.78 \\
\hline 2,5 Bis-(tri fluoro methyl)-aniline & 0.42 & 0.97 \\
\hline Dutasteride 17a-Epimer & 0.92 & 0.95 \\
\hline Dutasteride & 1.00 & 1.00 \\
\hline
\end{tabular}

Table 2: Results for system suitability

\begin{tabular}{|c|c|c|}
\hline System suitability & Observed value & Acceptance criteria \\
\hline $\begin{array}{c}\text { Resolution between Dutasteride } \\
\text { and Dutasteride 17a-Epimer }\end{array}$ & 3.2 & $\geq 1.5$ \\
\hline $\begin{array}{c}\text { Asymmetry for Dutasteride peak } \\
\text { from standard }\end{array}$ & 1.1 & $\leq 2.0$ \\
\hline $\begin{array}{c}\% \text { RSD for area of six replicate } \\
\text { injections of standard preparation }\end{array}$ & 0.5 & $\leq 5.0$ \\
\hline
\end{tabular}

RSD - relative standard deviation

Table 3: regression statistic values for dutasteride and its impurities

\begin{tabular}{|c|c|c|c|c|}
\hline Parameter & Dutasteride & $\begin{array}{c}\text { Dutasteride } \\
\text { 17a-epimer }\end{array}$ & $\begin{array}{c}\text { 2,5 Bis-(tri fluoro } \\
\text { methyl)-aniline }\end{array}$ & Dutasteride \\
\hline Slope & 67142.0 & 81567.9 & 82986.0 & 85566.5 \\
\hline Intercept & -7237.6 & 3494.8 & 1156.1 & 5205.4 \\
\hline Correlation Coefficient & 0.999 & 1.000 & 1.000 & 1.000 \\
\hline Percent Bias at 100\% Level & -2.2 & 0.8 & 0.3 & 1.2 \\
\hline RRF & 0.78 & 0.95 & 0.97 & 1.00 \\
\hline
\end{tabular}

$\mathrm{RRF}$ - relative response factor

Table 4: Sensitivity results for dutasteride and impurities

\begin{tabular}{|c|c|c|}
\hline Drug/impurity name & LOD $(\boldsymbol{\mu g} / \mathbf{m L})$ & $\begin{array}{c}\mathbf{L O Q} \\
(\boldsymbol{\mu \mathbf { g }} / \mathbf{m L})\end{array}$ \\
\hline Dutasteride acid & 0.1538 & 0.4660 \\
\hline 2,5 Bis-(tri fluoro methyl)-aniline & 0.1153 & 0.3493 \\
\hline Dutasteride 17a-epimer & 0.1307 & 0.3962 \\
\hline Dutasteride & 0.1324 & 0.4012 \\
\hline
\end{tabular}


Table 5: Method precision findings for

individual impurities and dutasteride

\begin{tabular}{|c|c|c|c|c|c|c|c|c|}
\hline \multirow[t]{2}{*}{ Sample No. } & \multicolumn{2}{|c|}{ Dutasteride Acid } & \multicolumn{2}{|c|}{$\begin{array}{l}\text { 2,5 Bis-(tri fluoro } \\
\text { methyl)-aniline }\end{array}$} & \multicolumn{2}{|c|}{$\begin{array}{c}\text { Dutasteride } 17 \alpha- \\
\text { Epimer }\end{array}$} & \multirow{2}{*}{$\begin{array}{c}\text { Percent } \\
\text { total } \\
\text { impurities }\end{array}$} & \multirow{2}{*}{$\begin{array}{c}\text { Percent } \\
\text { dutasteride }\end{array}$} \\
\hline & RRT & $\%$ & RRT & $\%$ & RRT & $\%$ & & \\
\hline 1 & 0.20 & 1.093 & 0.42 & 1.093 & 0.92 & 1.033 & 3.219 & 0.934 \\
\hline 2 & 0.20 & 1.084 & 0.42 & 1.061 & 0.92 & 1.031 & 3.176 & 0.934 \\
\hline 3 & 0.20 & 1.067 & 0.42 & 1.037 & 0.92 & 1.011 & 3.115 & 0.944 \\
\hline 4 & 0.20 & 1.043 & 0.42 & 1.060 & 0.92 & 1.011 & 3.114 & 0.960 \\
\hline 5 & 0.20 & 1.016 & 0.42 & 1.050 & 0.92 & 1.019 & 3.085 & 0.977 \\
\hline 6 & 0.20 & 1.073 & 0.42 & 1.029 & 0.92 & 1.001 & 3.103 & 0.995 \\
\hline Average & 0.20 & 1.063 & 0.42 & 1.055 & 0.92 & 1.018 & 3.135 & 0.957 \\
\hline RSD & - & 2.7 & - & 1.093 & - & 1.2 & 1.6 & 2.6 \\
\hline
\end{tabular}

RRT - relative retention time; RSD - relative standard deviation

Table 6: Intermediate precision/ruggedness

findings for individual impurities and dutasteride

\begin{tabular}{|c|c|c|c|c|c|c|c|c|}
\hline \multirow[t]{2}{*}{ Sample No. } & \multicolumn{2}{|c|}{ Dutasteride Acid } & \multicolumn{2}{|c|}{$\begin{array}{c}\text { 2,5 Bis-(tri fluoro } \\
\text { methyl)-aniline }\end{array}$} & \multicolumn{2}{|c|}{$\begin{array}{l}\text { Dutasteride 17a- } \\
\text { Epimer }\end{array}$} & \multirow{2}{*}{$\begin{array}{l}\text { Percent total } \\
\text { impurities }\end{array}$} & \multirow[t]{2}{*}{$\begin{array}{c}\text { Percent } \\
\text { dutasteride }\end{array}$} \\
\hline & RRT & $\%$ & RRT & $\%$ & RRT & $\%$ & & \\
\hline 1 & 0.20 & 1.095 & 0.42 & 0.993 & 0.92 & 1.051 & 3.139 & 0.887 \\
\hline 2 & 0.20 & 1.074 & 0.43 & 1.007 & 0.92 & 1.044 & 3.125 & 0.928 \\
\hline 3 & 0.20 & 1.067 & 0.43 & 1.081 & 0.92 & 1.034 & 3.182 & 0.931 \\
\hline 4 & 0.20 & 1.050 & 0.43 & 1.019 & 0.92 & 1.078 & 3.147 & 0.912 \\
\hline 5 & 0.20 & 1.089 & 0.43 & 1.042 & 0.92 & 1.062 & 3.193 & 0.920 \\
\hline 6 & 0.20 & 1.039 & 0.43 & 1.031 & 0.92 & 1.053 & 3.123 & 0.911 \\
\hline Average & 0.20 & 1.069 & 0.43 & 1.029 & 0.92 & 1.054 & 3.152 & 0.915 \\
\hline RSD & - & 2.0 & - & 3.0 & - & 1.4 & 0.9 & 1.7 \\
\hline
\end{tabular}

RRT - relative retention time; RSD - relative standard deviation

Table 7: Accuracy for impurities at varying concentration levels

\begin{tabular}{|c|c|c|c|}
\hline Spike Level & $\begin{array}{l}\mu \mathrm{g} / \mathrm{mL} \\
\text { quantity } \\
\text { added }\end{array}$ & $\begin{array}{c}\text { Mean } \\
\text { percent } \\
\text { recovery }\end{array}$ & $\begin{array}{c}\% \\
\text { RSD }\end{array}$ \\
\hline \multicolumn{4}{|c|}{ Dutasteride acid } \\
\hline $\mathrm{LOQ}$ & 0.4660 & 90.1 & 1.0 \\
\hline $50 \%$ & 2.4875 & 97.4 & 1.3 \\
\hline $100 \%$ & 4.9750 & 102.2 & 2.4 \\
\hline $150 \%$ & 7.4625 & 100.5 & 1.3 \\
\hline \multicolumn{3}{|c|}{ Overall percent RSD } & 5.1 \\
\hline \multicolumn{4}{|c|}{ 2, 5 Bis-(tri fluoro methyl)-aniline } \\
\hline $\mathrm{LOQ}$ & 0.3493 & 87.2 & 6.6 \\
\hline $50 \%$ & 2.5449 & 102.0 & 0.8 \\
\hline $100 \%$ & 5.0898 & 100.9 & 1.5 \\
\hline $150 \%$ & 7.6347 & 98.4 & 0.4 \\
\hline \multicolumn{3}{|c|}{ Overall percent RSD } & 6.8 \\
\hline \multicolumn{4}{|c|}{ Dutasteride17a-Epimer } \\
\hline $\mathrm{LOQ}$ & 0.3962 & 95.3 & 3.5 \\
\hline $50 \%$ & 2.5420 & 101.5 & 0.7 \\
\hline $100 \%$ & 5.0839 & 103.4 & 0.8 \\
\hline $150 \%$ & 7.6259 & 101.9 & 0.5 \\
\hline \multicolumn{3}{|c|}{ Overall percent RSD } & 3.6 \\
\hline
\end{tabular}


Table 8: Robustness findings - RRT and their differences

\begin{tabular}{|c|c|c|c|c|c|c|}
\hline \multirow{2}{*}{ Flow rate } & \multicolumn{2}{c|}{ Dutasteride acid } & \multicolumn{2}{c|}{$\begin{array}{c}\text { 2,5 Bis-(tri fluoro } \\
\text { methyl)-aniline }\end{array}$} & $\begin{array}{c}\text { Dutasteride 17a- } \\
\text { Epimer }\end{array}$ \\
\cline { 2 - 7 } & RRT & Diff & RRT & Diff & RRT & Diff \\
\hline \multicolumn{7}{|c|}{ Variation in pH } \\
\hline 1.0 & 0.20 & NA & 0.41 & NA & 0.92 & NA \\
\hline 0.9 & 0.21 & 0.01 & 0.43 & 0.02 & 0.92 & 0.00 \\
\hline 1.1 & 0.19 & 0.01 & 0.40 & 0.01 & 0.91 & 0.01 \\
\hline \multicolumn{7}{|c|}{ Variation in temperature } \\
\hline $50^{\circ} \mathrm{C}$ & 0.20 & NA & 0.41 & NA & 0.92 & NA \\
\hline $45^{\circ} \mathrm{C}$ & 0.20 & 0.00 & 0.42 & 0.01 & 0.92 & 0.00 \\
\hline $55^{\circ} \mathrm{C}$ & 0.20 & 0.00 & 0.41 & 0.00 & 0.91 & 0.01 \\
\hline \multicolumn{7}{|c|}{ Variation in organic solvent ratio } \\
\hline $2 \%$ lower & 0.20 & NA & 0.41 & NA & 0.92 & NA \\
\hline Actual & 0.20 & 0.00 & 0.41 & 0.00 & 0.92 & 0.00 \\
\hline $2 \%$ higher & 0.20 & 0.00 & 0.42 & 0.01 & 0.91 & 0.01 \\
\hline \multicolumn{7}{|c|}{ Variation in wavelength } \\
\hline 205 & 0.20 & NA & 0.41 & NA & 0.92 & NA \\
\hline 210 & 0.20 & 0.00 & 0.41 & 0.00 & 0.92 & 0.00 \\
\hline 215 & 0.20 & 0.00 & 0.41 & 0.00 & 0.92 & 0.00 \\
\hline
\end{tabular}

RRT - relative retention time; Diff - difference

Table 9: Forced Degradation results of dutasteride capsules

\begin{tabular}{|c|c|c|c|c|c|c|c|c|}
\hline & \multirow{2}{*}{ Control } & \multicolumn{6}{|c|}{ Degradation } \\
\hline & & & Acid & Base & Peroxide & Light & Thermal & Humidity \\
\hline \multicolumn{2}{|l|}{ Peak Purity } & 1.000 & 1.000 & 1.000 & 1.000 & 1.000 & 1.000 & 1.000 \\
\hline Compounds & RRT & \multicolumn{7}{|c|}{$\%$ impurity } \\
\hline Dutasteride & 1.00 & NA & NA & NA & NA & NA & NA & NA \\
\hline Dutasteride acid & & ND & ND & ND & ND & ND & ND & ND \\
\hline $\begin{array}{c}2,5 \text { Bis-(tri fluoro } \\
\text { methyl)aniline }\end{array}$ & 0.43 & 0.021 & ND & 0.008 & 0.016 & 0.022 & 0.025 & 0.020 \\
\hline Dutasteride 17a-Epimer & 0.92 & 0.039 & ND & ND & 0.263 & 0.035 & 0.033 & 0.054 \\
\hline Chloro Dutasteride & 1.05 & 0.017 & 0.024 & ND & 0.025 & 0.040 & 0.021 & 0.026 \\
\hline Total impurities & & 0.060 & 0 & 0.008 & 0.279 & 0.057 & 0.058 & 0.074 \\
\hline$\%$ Net degradation & & & 0 & 0 & 0 & 0 & 0 & 0 \\
\hline Mass Balance (\%) & & & 101 & 100 & 101 & 101 & 101 & 102 \\
\hline
\end{tabular}

NA - not available; ND - not detected; RRT - relative retention time<smiles>C[C@]12C=CC(=O)N[C@H]1CCC1[C@@H]2CC[C@]2(C)[C@@H](C(=O)Nc3cc(C(F)(F)F)ccc3C(F)(F)F)CC[C@@H]12</smiles>

[a]<smiles>C[C@]12CC[C@H]3C(CC[C@@H]4NC(=O)C=C[C@@H]43)[C@@H]1CC[C@@H]2C(=O)O</smiles>

[b]<smiles>C[C@]12CC[C@H]3[C@@H](CC[C@H]4NC(=O)C=C[C@]34C)[C@@H]1CC[C@@H]2C(=O)Nc1cc(C(F)(F)F)ccc1C(F)(F)F</smiles><smiles>Nc1cc(C(F)(F)F)ccc1C(F)(F)F</smiles>

[d]

[c]

Fig. 1: [a] Dutasteride [b] Dutasteride acid [c] Dutasteride $17 \alpha$-Epimer [d] 2,5 Bis-(tri fluoro methyl)-aniline 


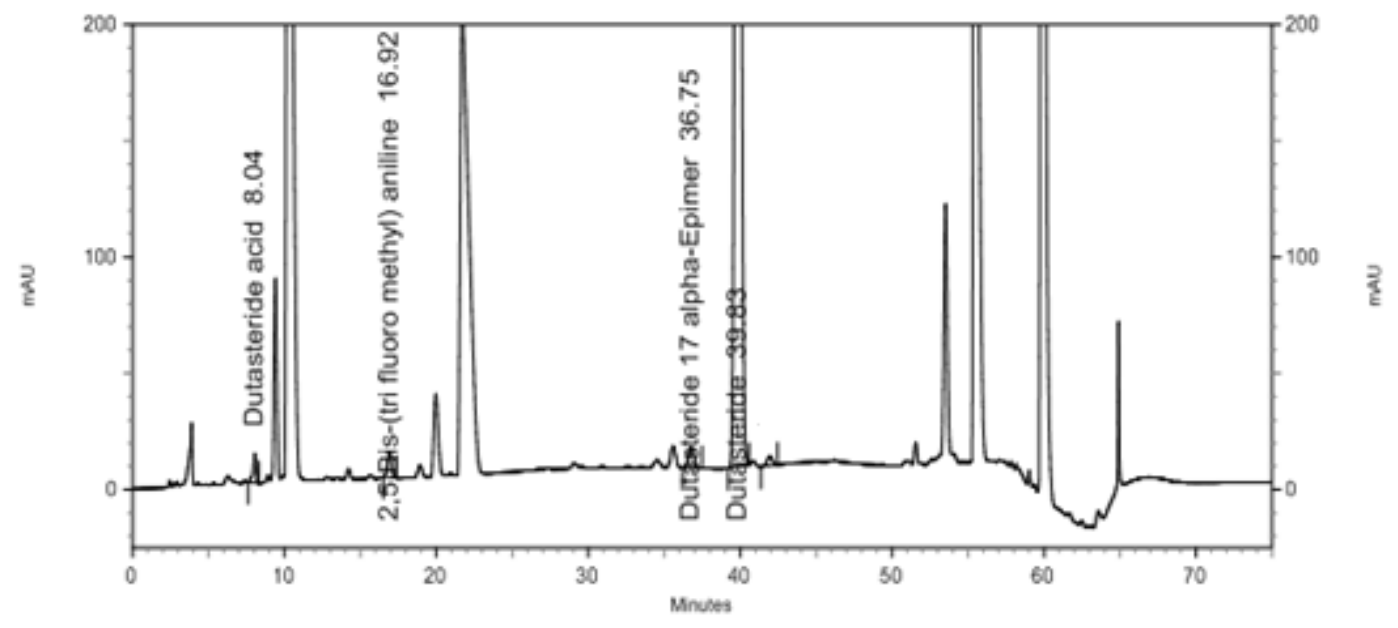

Fig. 2: Dutasteride acid (RT 8.04 min), 2,5 Bis-(tri fluoro methyl)-aniline (RT $16.92 \mathrm{~min}$ ), Dutasteride 17a-epimer (RT $36.75 \mathrm{~min}$ ) and Dutasteride (RT $38.83 \mathrm{~min}$ ) chromatogram

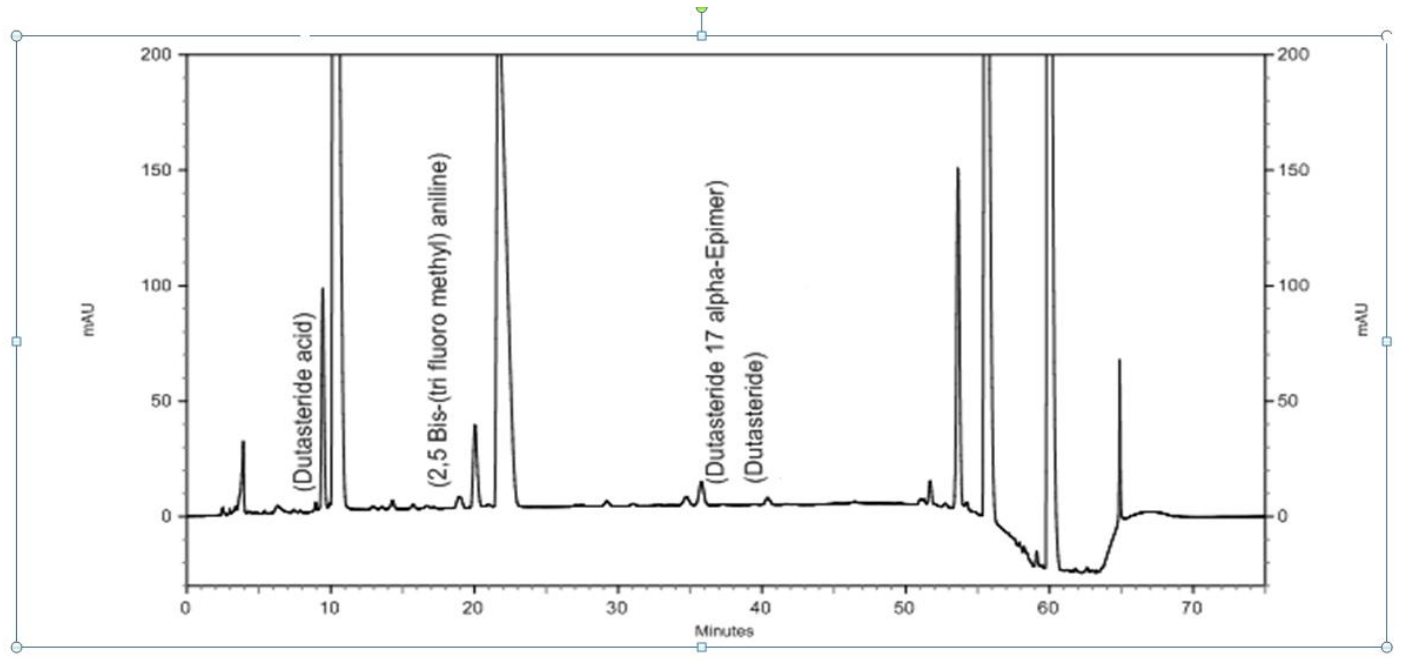

Fig. 3a: Placebo chromatogram

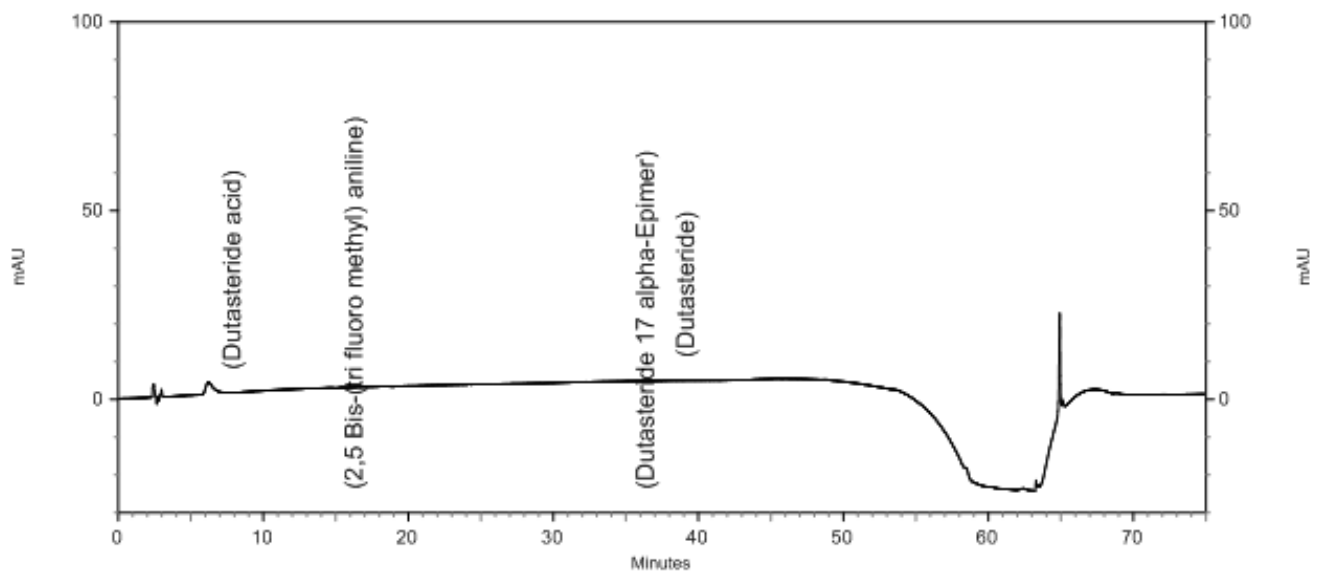

Fig. 3b: Diluent chromatogram 


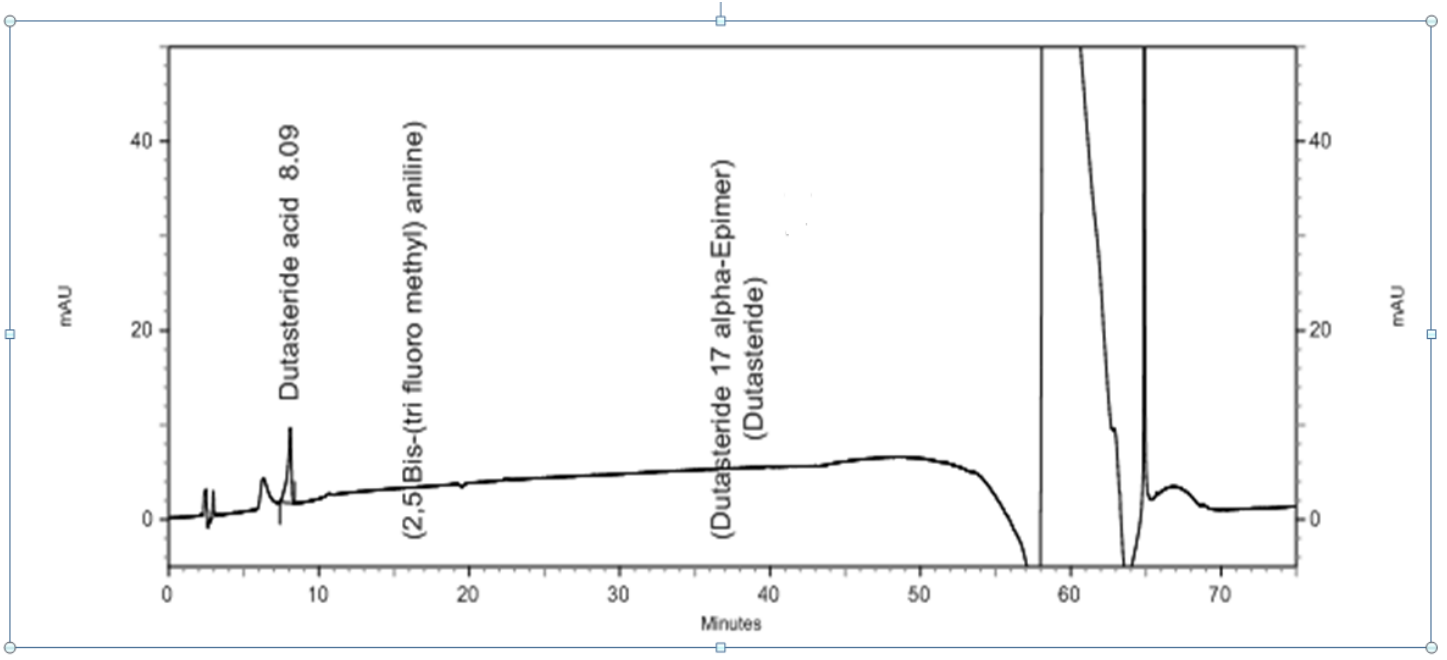

Fig. 4a: Dutasteride acid chromatogram

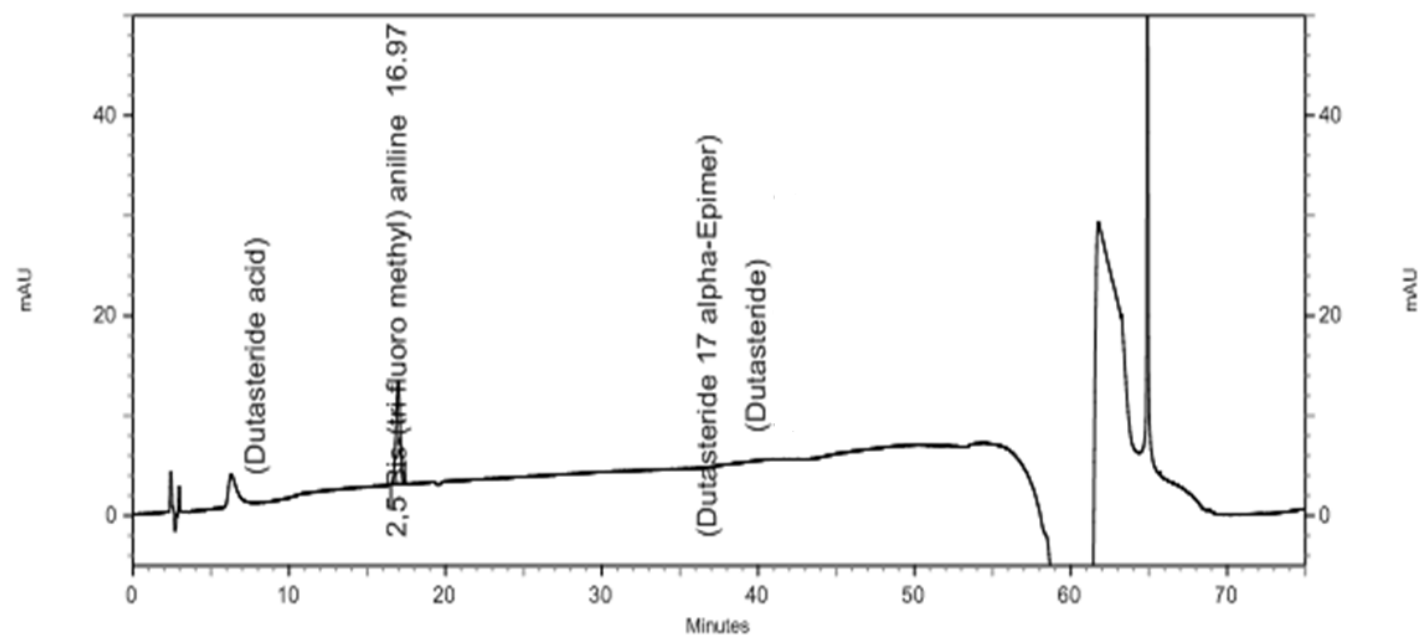

Fig. 4b: 2, 5 Bis-(tri fluoro methyl)-aniline chromatogram

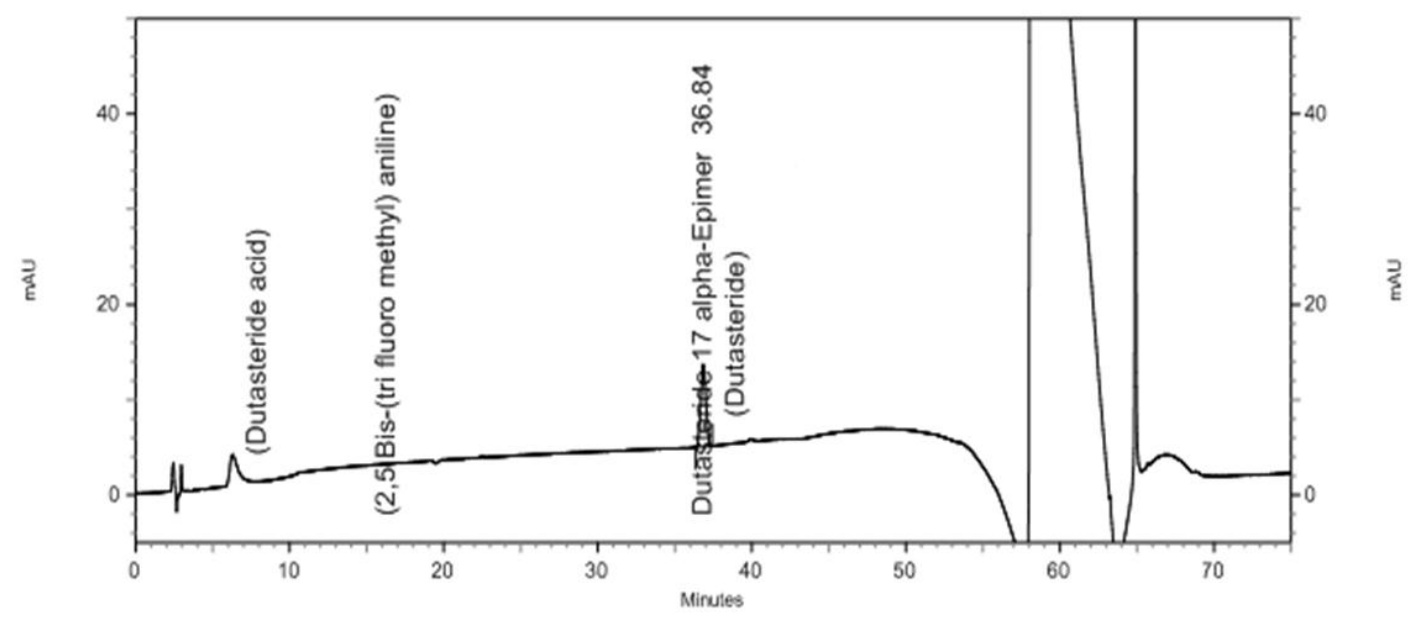

Fig. 4c: Dutasteride 17a-Epimer chromatogram 


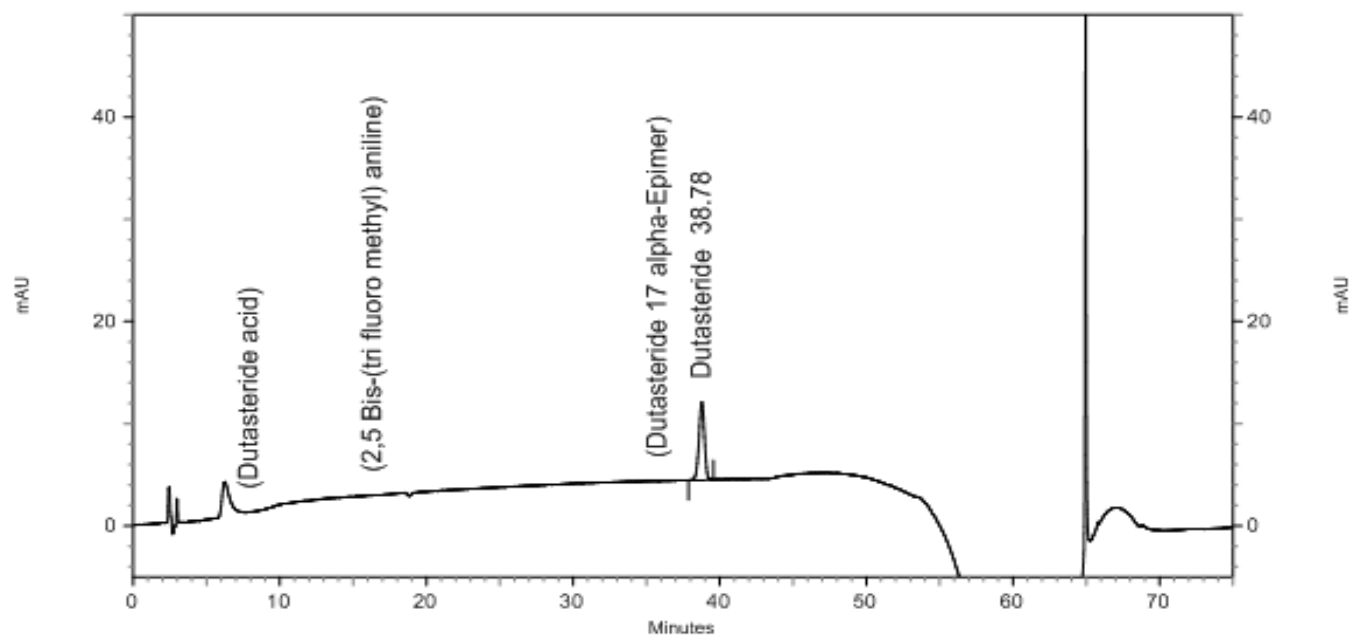

Fig. 4d: Dutasteride chromatogram

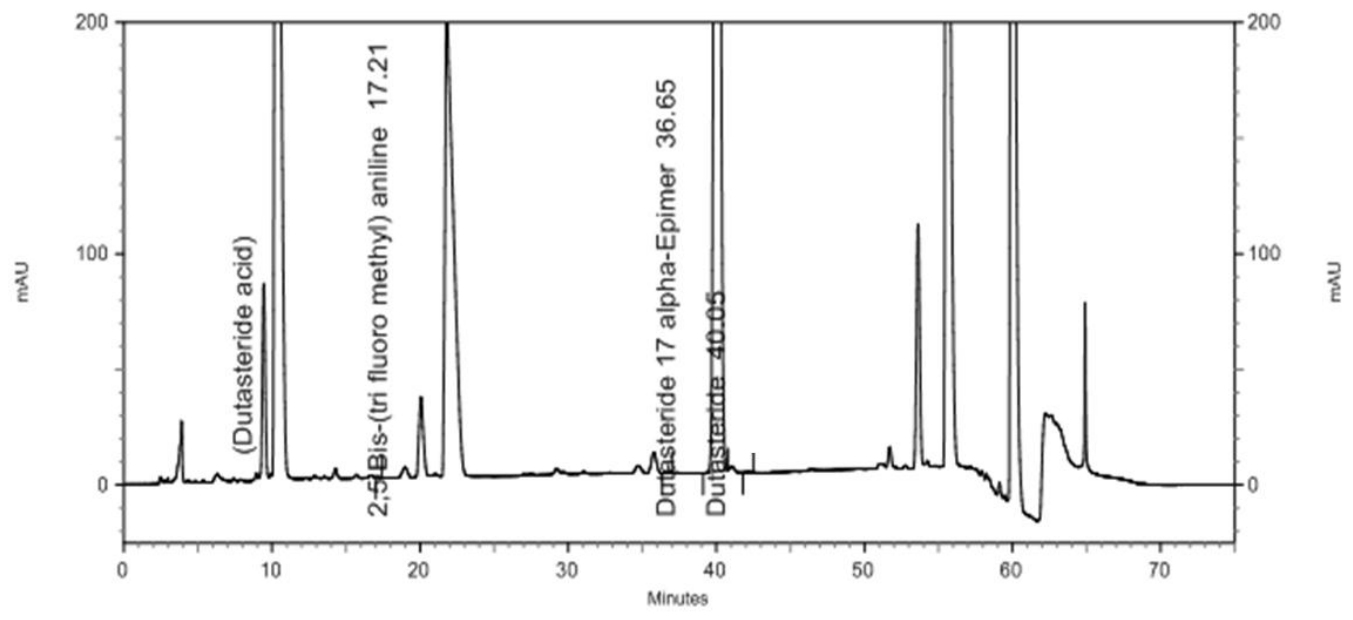

Fig. 4e: Control test chromatogram

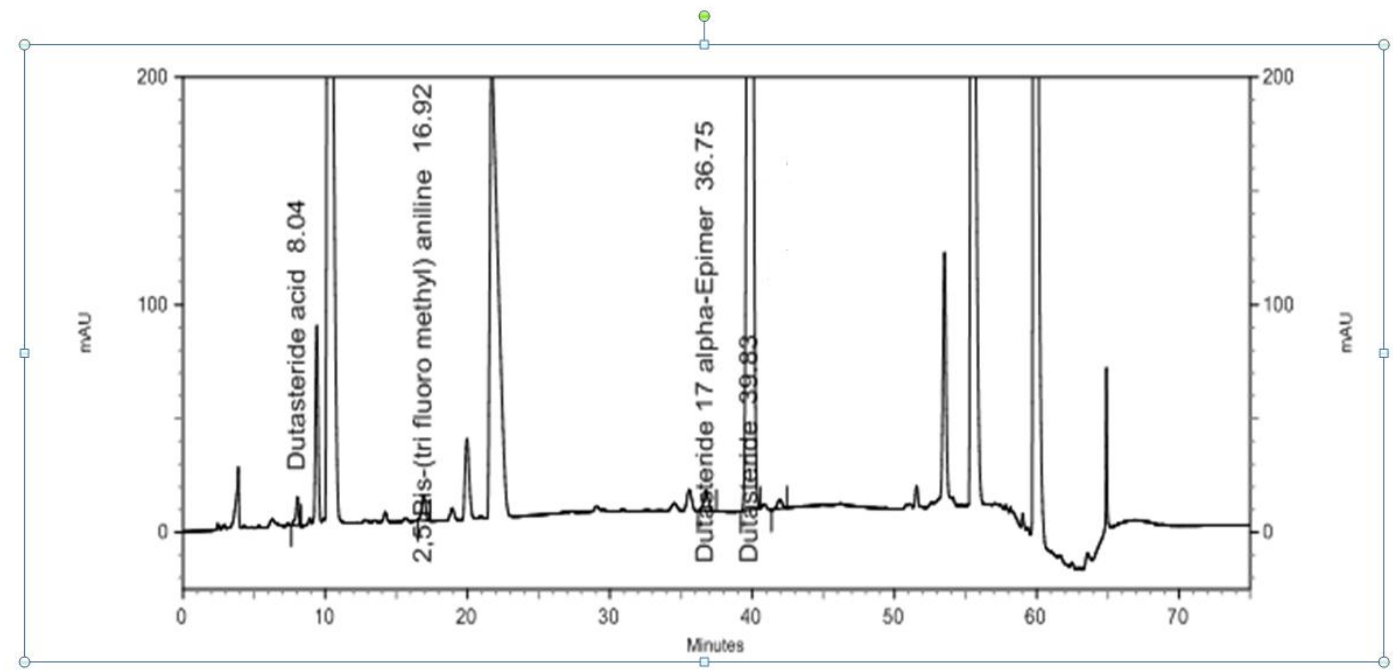

Fig. 4f: Spiked test chromatogram 


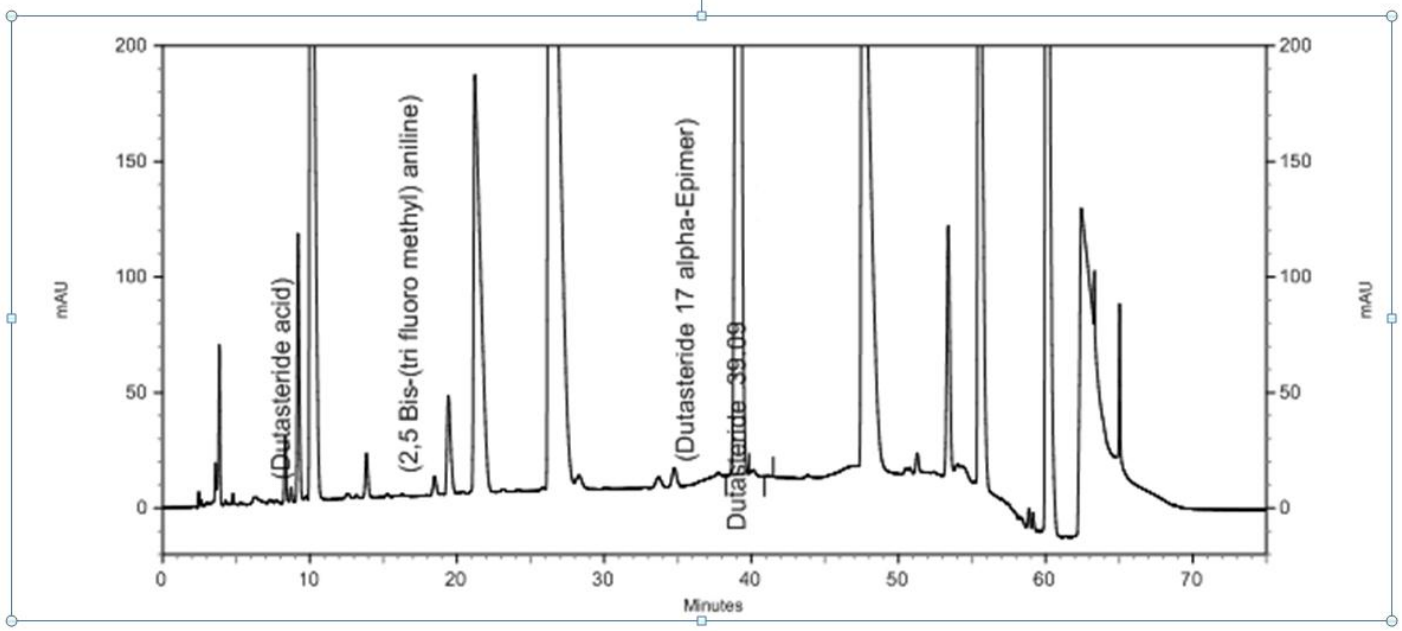

Fig. 5a: Chromatogram of acid stressed capsule

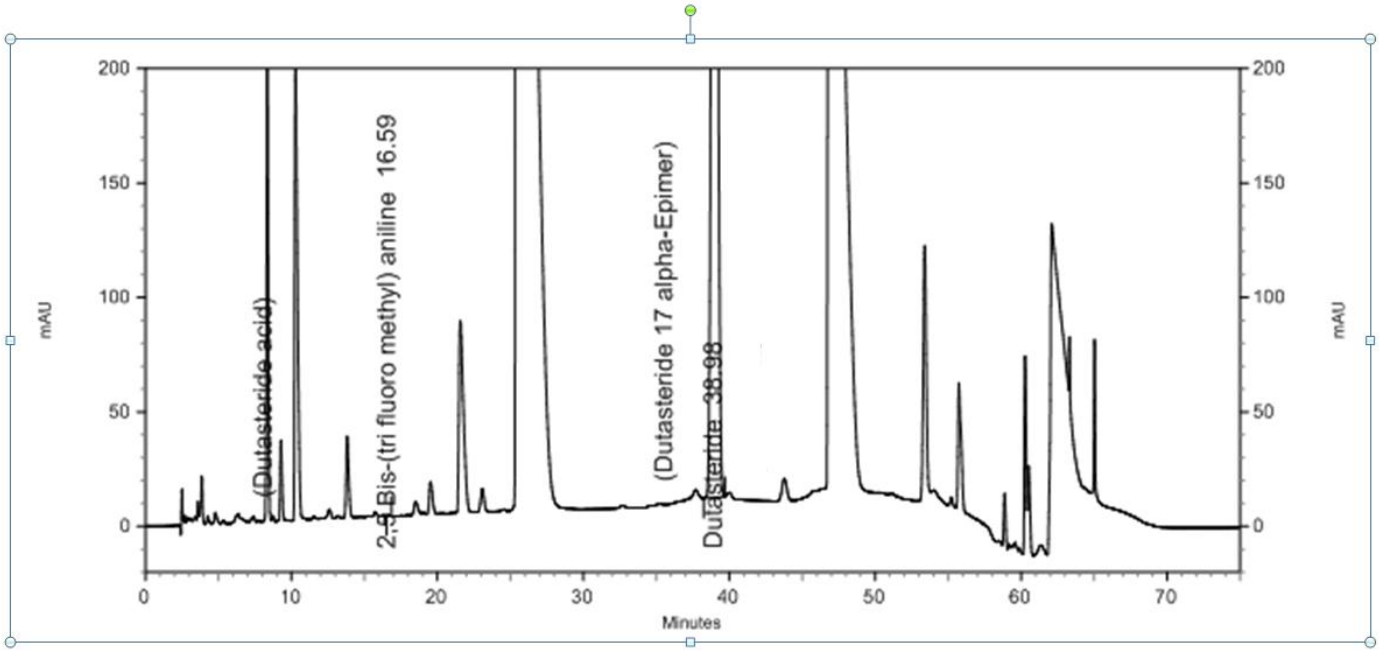

Fig. 5b: Chromatogram of alkali stressed capsule

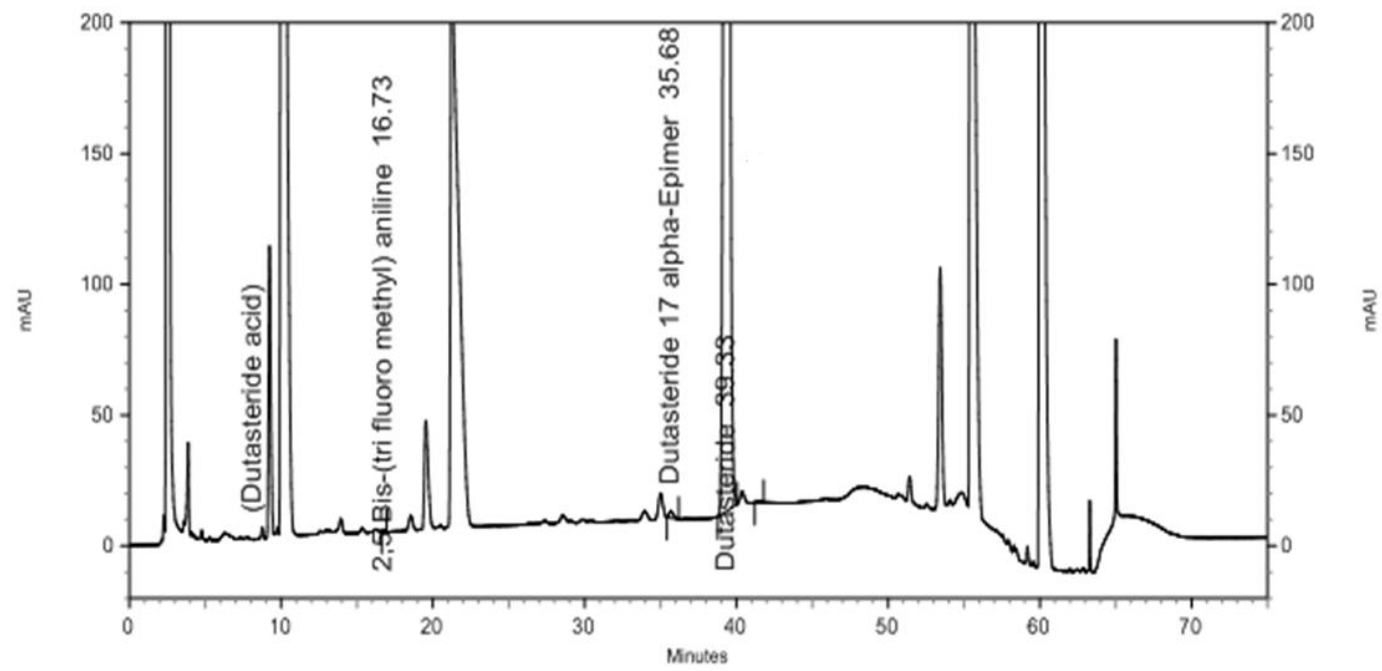

Fig. 5c: Chromatogram of peroxide stressed capsule 


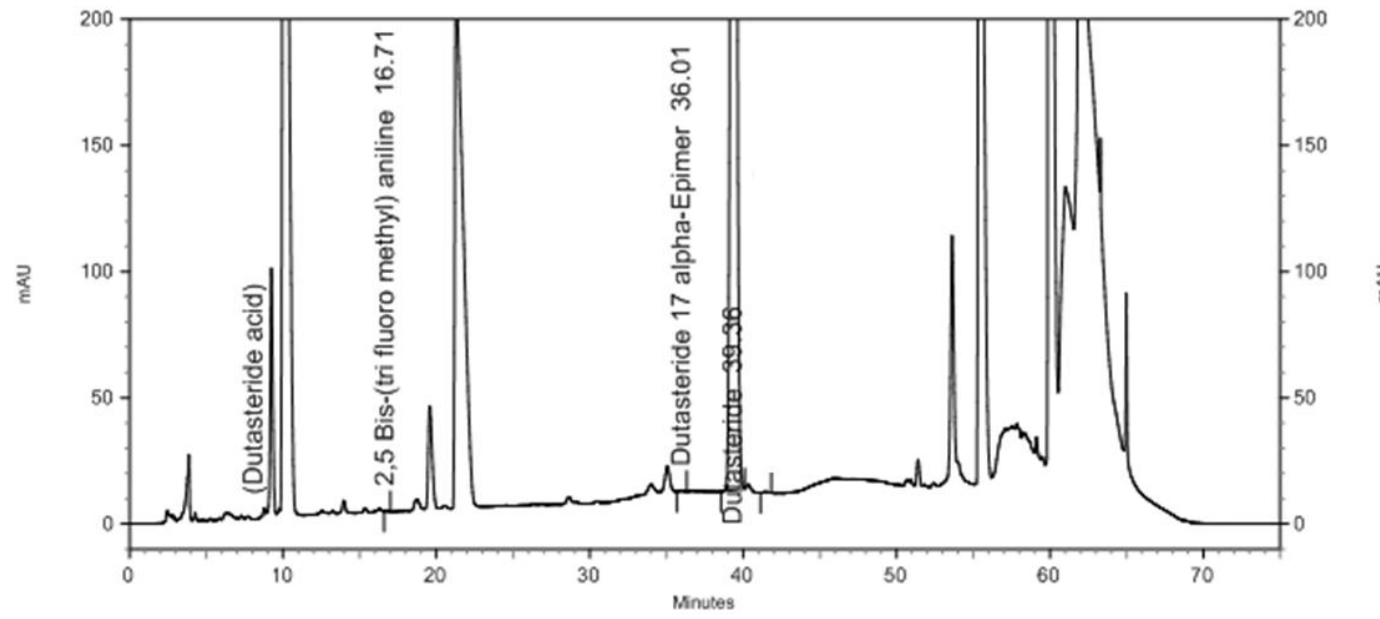

Fig. 5d: Chromatogram of photo stressed capsule

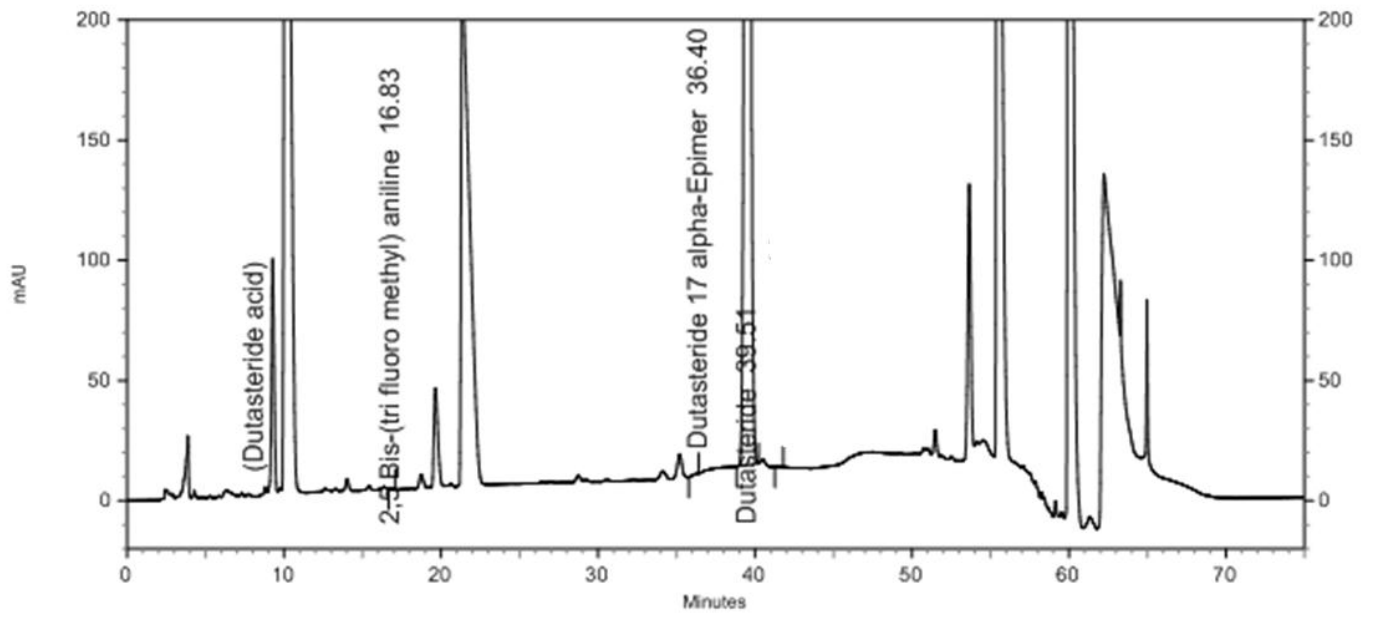

Fig. 5e: Chromatogram of thermal stressed capsule

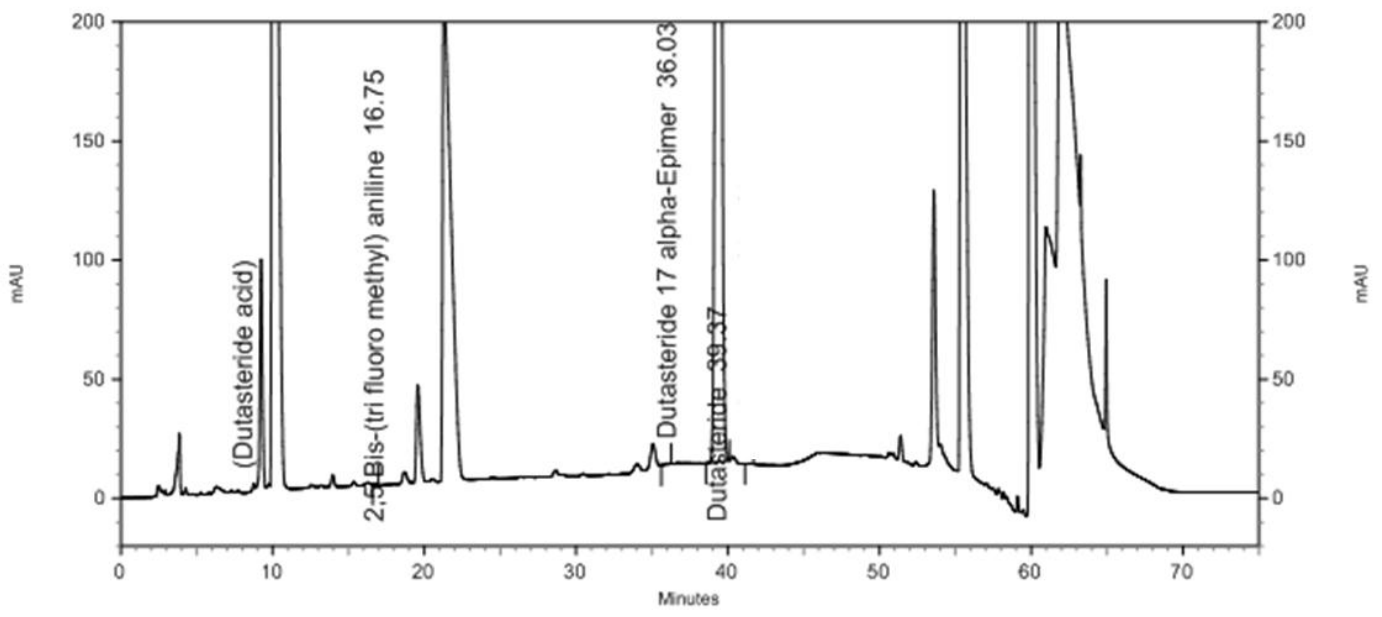

Fig. 5f: Chromatogram of humidity stressed capsule 


\section{REFERENCES}

1. Dutasteride, Drug bank, Accessed on July 2019. Available at: https://www.drugbank.ca/drugs/DB01126

2. Dutasteride, Pubchem, Accessed on July 2019. Available at: https://pubchem.ncbi.nlm.nih.gov/compou nd/Dutasteride

3. Kim EH, Brockman JA and Andriole GL. The use of 5-alpha reductase inhibitors in the treatment of benign prostatic hyperplasia. Asian J Urol. 2018;5(1):2832.

4. Hirshburg JM, Kelsey PA, Therrien CA, Gavino AC and Reichenberg JS. Adverse effects and safety of 5-alpha reductase inhibitors (Finasteride, Dutasteride): A Systematic Review. J Clin Aesthet Dermatol. 2016;9(7):56-62.

5. Ehdaie B and Touijer KA. 5-alpha reductase inhibitiors in prostate cancer: from clinical trials to clinical practice. Eur Urol. 2013;63(5):788-791.

6. Traish A, Haider KS, Doros G and Haider A. Long-term dutasteride therapy in men with benign prostatic hyperplasia alters glucose and lipid profiles and increases severity of erectile dysfunction. Horm Mol Biol Clin Investig. 2017;30 (3): pii: /j/hmbci.2017.30.issue-3/hmbci-20170015/hmbci-2017-0015.xmL.

7. Shanshanwal SJ and Dhurat RS. Superiority of dutasteride over finasteride in hair regrowth and reversal of miniaturization in men with androgenetic alopecia: A randomized controlled openlabel, evaluator-blinded study. Indian J Dermatol, Venereol Leprol. 2017;83(1):47-54.

8. Contractor $\mathrm{P}$, Kurani H, Guttikar $\mathrm{S}$ and Shrivastav PS. Reliable and sensitive determination of dutasteride in human plasma by liquid chromatography-tandem mass spectrometry. Biomed Chromatogr. 2013:27(9):1168-1176.

9. Ranjani VA, Karthik K, Kumar JP, Kumar KSB and Prabhakar T. A validated method development of dutasteride in human plasma using LC-MS/MS. Int $\mathrm{J}$ Pharma Chem Sci. 2013; 2(1):266-272.

10. Myung JK, Ha RC, Dong HL, Dong WY, Young WC and Yong SC. A method to monitor dutasteride in rat plasma using liquid-liquid extraction and multiple reaction monitoring: comparisons and validation. Mass Spectr Lett. 2014;5(3);79-83.

11. Dipti BP, Natubhai JP, Sejal KP and Paresh UP. Validated stability indicating HPTLC method for the determination of dutasteride in pharmaceutical dosage forms. Chromatogr Res Int 2011; 2011: Article ID 278923, 5 pages.

12. Kamila MM, Mondal N and Ghosh LK. A validated spectrophotometric method for determination of dutasteride in bulk drug and pharmaceutical formulations. Int $\mathrm{J}$ PharmTech Res. 2010;2(1): 113-117.

13. Amin Md R, Moynul $H$, Al Masud A, Hanifuddin Md, Hasanuzzaman Md and Islam Md K, validated UV spectrophotometric method for estimation of dutasteride in tablet dosage form. Pharmacie Globale. Int J Compre Pharma. 2011;2(4):1-3.

14. Patel DB, Patel NJ, Patel SK, Prajapati AM and Patel SA. RP-HPLC method for the estimation of dutasteride in tablet dosage form. Indian J Pharma Sci. 2010;72(1):113-116.

15. Navaneeswari $R$ and Reddy PR. Development and validation of a RPHPLC method for dutasteride and its impurities in bulk drug. African J Sci Res. $2011 ; 6(1): 318-324$

16. Reddy YK, Reddy GVS, Veera KNJ and Hotha LL. A stability indicating UPLC method for dutasteride and its related impurities. American J PharmTech Res. 2012; 2(6): 702-715.

17. International Conference on Harmonization (ICH) of technical requirements for the registration of pharmaceutical for human use stability testing of new drugs substance and products Q1A (R2). 2003.

18. International Conference on Harmonization, ICH Guidelines, Validation of analytical procedures technical requirements for registration of pharmaceuticals for human use: Text and Methodology Q 2 (R1), International Conference on Harmonization, Geneva, Switzerland, 2005. 